\title{
Cytotoxic compounds from Laurencia pacifica
}

\author{
Diana A Zaleta-Pinet', Ian P Holland', Mauricio Muñoz-Ochoa², J Ivan Murillo-Alvarez², Jennette A Sakoff', \\ Ian A van Altena ${ }^{1}$ and Adam McCluskey ${ }^{1 *}$
}

\begin{abstract}
Background: The current investigation sought to explore the nature of the secondary metabolites in the algae, Laurencia pacifica.

Results: This report details the first isolation of the sesquiterpenes isoaplysin (1), isolaurenisol (2), debromoisolaurinterol (3), debromoaplysinol (4), laur-11-en-10-ol (5), 10a-hydroxyldebromoepiaplysin (6), and the previously unknown 10-bromo-3,7,11,11-tetramethylspiro[5.5]undeca-1,7-dien-3-ol (7) from the algae, Laurencia pacifica. Isoaplysin (1) and debromoaplysinol (4) showed promising levels of growth inhibition against a panel cancer-derived cell lines of colon (HT29), glioblastoma (U87, SJ-G2), breast (MCF-7), ovarian (A2780), lung (H460), skin (A431), prostate (Du145), neuroblastoma (BE2-C), pancreas (MIA), murine glioblastoma (SMA) origin with average $\mathrm{Gl}_{50}$ values of 23 and $14 \mu \mathrm{M}$.

Conclusions: Isoaplysin (1) and debromoaplysinol (4) were up to fourfold more potent in cancer-derived cell populations than in non-tumor-derived normal cells (MCF10A). These analogues are promising candidates for anticancer drug development.
\end{abstract}

Keywords: Laurencia pacifica; Algae; Sesquiterpenes; Anti-cancer; Cytotoxicity

\section{Findings}

\section{Introduction}

Natural products with their high fraction $s p^{3}$ content $\left(\mathrm{Fsp} p^{3}\right)$ represent a significant proportion of all clinical drugs [1]. Of the 1,355 new entities introduced as therapeutics between 1981 and 2010, 71\% were natural products or natural product derived [2]. A high $\mathrm{Fsp}^{3}$ content imbues natural products with defined three-dimensional geometry that allows for high levels of interaction with a wide range of biological targets. A significant number of natural products adhere to the 'rule of five' and thus present high levels of drug-like character [3,4]. Natural products also afford access to a wide range of novel chemical motifs accessing new chemical space in the drug design and development arena. This has led to the ongoing interest in accessing natural product secondary metabolites (in particular) with their high chemical diversity and biological specificity, making them a favorable source of lead compounds for drug discovery and development $[5,6]$.

Recently, we turned our attention to marine natural products as a potential source for new lead compounds.

\footnotetext{
* Correspondence: Adam.McCluskey@newcastle.edu.au

${ }^{1}$ Chemistry, School of Environmental and Life Science, The University of

Newcastle, University Drive, Callaghan, NSW 2308, Australia

Full list of author information is available at the end of the article
}

In this area, we have identified a small family of cytotoxic steroids from an Australian sponge Psammoclema sp. [7], and antimalarial, antialgal, antitubercular, antibacterial, antiphotosynthetic, and antifouling activity of diterpene and diterpene isonitriles from the tropical marine sponge Cymbastela hooperi [8]. In this present study, we examined the cytotoxicity of extracts obtained from Laurencia pacifica algae collected in the pacific coast of the Baja California Peninsula, Mexico.

The genus Laurencia typically inhabits the world's tropical oceans and has been responsible for approximately half of all the reported compounds from red algae. This genus is considered an important producer of halogenated sesquiterpenes, diterpenes, and acetogenins [9-11]. Biological activities of the Laurencia family range from antipredatory [12], antifungal [13], antibacterial [14-16], to anticancer [17-19]. Secondary metabolites reported from L. pacifica include $\gamma$-bisabolene, bromocuparane, laurinterol, debromolauriterol, isolaurinterol, aplysin, debromoaplysin, 10-bromo- $\alpha$-chamigrene, prepacifenol, pacifenol, pacifidine, and kylinone [10].

\section{Results and discussion}

The algae, L. pacifica was collected from the Baja California Peninsula, Mexico. The ethanol extracts were examined for 
the potential presence of cytotoxic compounds. Cytotoxicity screening was conducted against a panel of cancer cell lines of colon (HT29), glioblastoma (U87, SJ-G2), breast (MCF-7), ovarian (A2780), lung (H460), skin (A431), prostate (Du145), neuroblastoma (BE2-C), pancreas (MIA), murine glioblastoma (SMA) origin, and a normal line of breast cells (MCF10A) [20]. The preliminary screening showed sufficient promise to embark on an isolation program (data not shown).

Bioassay-guided fractionation (normal phase chromatography) of the L. pacifica ethanolic extracts (see Additional file 1) resulted in the isolation of seven sesquiterpenes: isoaplysin (1) [21,22], isolaurenisol (2) [13,22], debromoisolaurinterol (3) [23], debromoaplysinol (4) [10,13,21], laur-11-en-10-ol (5) [13], 10 $\alpha$-hydroxyldebromoepiaplysin (6) [13] (Figure 1) and the previously unreported 10bromo-1,7-dien-3-ol (7) (Figure 2). Sesquiterpenes 1 to 6 were identified in comparison with their spectroscopic data against literature data [21-23].

Sesquiterpenes $\mathbf{1}$ to $\mathbf{6}$ have been found in other Laurencia algae: L. okumurai, (1, 2, 3, 4, and 6) [21,22], L. gracilis (2) [24,25], L. tristicha (5) [19], and L. distichophylla (3) [26]. This work represents the first identification of these sequiterpenes in L. pacifica.

Sesquiterpene 7 was isolated in very small quantities (approximately $100 \mathrm{ng}$ ) from $2 \mathrm{~kg}$ of algae and was identified through a combination of high resolution mass spectrometry, infrared spectroscopy, and heteronuclear multiple bond correlation (HMBC), heteronuclear single quantum correlation (HSQC), correlated spectroscopy (COSY) NMR (see Additional file 1). The spectral data obtained closely matched reported spectral data of the related 10-bromo-7,8-expoxychamigr-1-en-3-ol (8) (Figure 2) [26], in which the C6 stereochemistry was determined by detailed NMR analysis and was consistent with our data [27-29]. The peak assignment and spectral comparison of $\mathbf{7}$ and $\mathbf{8}$ are shown in Table 1. There are three related structures with the $\mathrm{C} 1-\mathrm{C} 2$ double bond, one of which is supported by crystal structure data and is of the same absolute configuration as shown for 7 and $\mathbf{8}$. While these data are wholly consistent with our assignment, Suescun et al. have identified another compound with the opposite C6 configuration [29]. We thus consider our absolute configuration assignment as tentative. Notwithstanding this, the spectroscopic data is consistent with the assigned structure and represents a new sesquiterpene from L. pacifica (Figure 2).

Sequiterpenes $\mathbf{1}$ to $\mathbf{5}$ were isolated in sufficient quantities allowing direct evaluation as pure compounds against a panel of cancer and non-cancer-derived cell lines. Due to the low levels of sesquiterpenes 6 and 7, these were screened as a 1:1 mixture (both were isolated from the same extract fraction as determined by ${ }^{1} \mathrm{H}$ NMR) [30]. Initial cytotoxicity screening was conducted at a single dose of $25 \mu \mathrm{M}$, and these data are presented in Table 2.

Analysis of the cytotoxicity data presented in Table 2 highlights the low level of cell death of the 12 cell lines examined on treatment with $2,3,5$, and 6/7. Isoaplysin (1) and debromoaplysinol (4) displayed promising levels of cell death from $10 \%$ to $>100 \%$ and $31 \%$ to $>100 \%$ at $25 \mu \mathrm{M}$ drug concentration, respectively. Of the other analogues, only isolaurenisol (2) displayed any growth inhibition at $>20 \%$ (Du145, prostate cancer cell line). Given the activities of these three analogues, a full dose response evaluation was undertaken across our panel of carcinoma and normal cell lines [20]. These data are presented in Table 3.

As anticipated, isolaurenisol (2) displayed no noteworthy cytotoxicity returning a $\mathrm{GI}_{50}$ value $>50 \mu \mathrm{M}$ across all cell lines examined. Both isoaplysin (1) and debromoaplysinol (4) displayed good to excellent levels of cytotoxicity. Isoaplysin (1) returned an average $\mathrm{GI}_{50}$ value of $23 \mu \mathrm{M}$ (from $15 \pm 1.2 \mu \mathrm{M}$ to $40 \pm 0.6 \mu \mathrm{M}$ against the HT29 and U87 cell lines, respectively), while debromoaplysinol (4) returned an average $\mathrm{GI}_{50}$ value of $14 \mu \mathrm{M}$ (from $6.8 \pm$ $0.3 \mu \mathrm{M}$ to $26 \pm 1.7 \mu \mathrm{M}$ against the Du145 and U87 cell
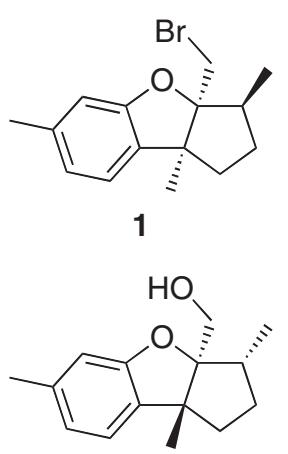

4<smiles>Cc1ccc([C@]2(C)CC/C(=C\Br)[C@@H]2C)c(O)c1</smiles>

2

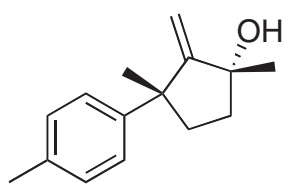

5<smiles>C=C1[C@H](C)CC[C@@]1(C)c1ccc(C)cc1O</smiles>

3

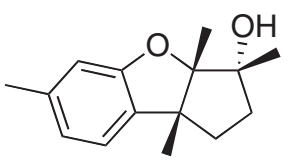

6

Figure 1 Chemical structures of the known sesquiterpenes isolated from Laurencia pacifica in this work. Isoaplysin (1), isolaurenisol (2), debromoisolaurinterol (3), debromoaplysinol (4), laur-11-en-10-ol (5), and 10a-hydroxyldebromoepiaplysin (6). 

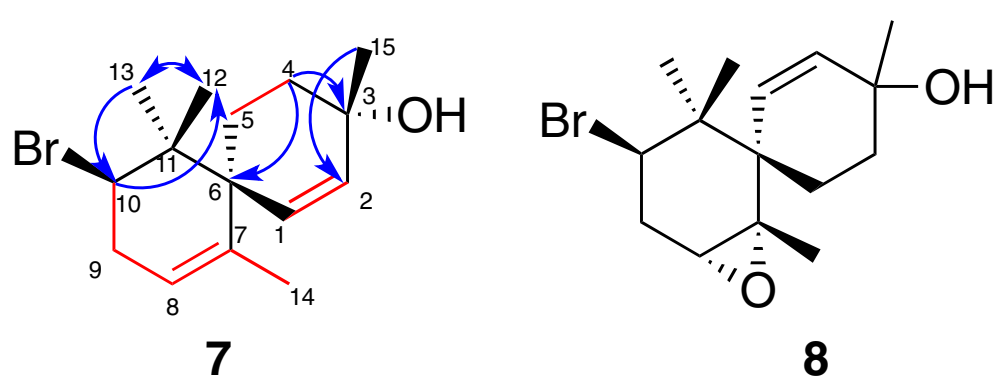

Figure 2 Important HMBC (blue arrows) and COSY (bold bonds) correlations for 7, and the chemical structure of the related 10-bromo-7,8-epoxychamigr-1-en-3-ol (8).

lines, respectively) when screened in cancer-derived cell lines. Both compounds showed the greatest growth inhibitory effect in the prostate cancer-derived cell line Du145 with $\mathrm{GI}_{50}$ values of 12 and $6.8 \mu \mathrm{M}$, respectively, and the least growth inhibitory effect in the non-cancer-derived normal breast cells with $\mathrm{GI}_{50}$ values of 46 and $28 \mu \mathrm{M}$, respectively. Indeed, $\mathbf{1}$ and $\mathbf{4}$ were up to fourfold more potent in cancer-derived cell populations than normal cells, imbuing them with properties favorable for future development as anti-cancer agents.
Given the structural similarity of the isolated analogues (1 to 6), being direct structural homologues or biosynthetically related, the observed differences in cytotoxicity suggest that the presence of the furan moiety and positioning and nature of the pendent substituents was important for cytotoxicity. Analogues $\mathbf{1}$ and $\mathbf{4}$ are $\mathrm{Br}-\mathrm{OH}$ bioisosteres, and $\mathbf{4}$ and $\mathbf{6}$ are positional isomers $(\mathrm{C} 3 \mathrm{a}-\mathrm{OH}(\mathbf{1})$ and a $\mathrm{C} 10 \mathrm{a}-\mathrm{OH}(\mathbf{6})$ ). The position of the $-\mathrm{OH}$ moiety is clearly important with the $3 \alpha$-hydroxydebromoaplysin (6) devoid of cytotoxicity, whereas debromoaplysinol (4) displays

Table 1 1D and 2D NMR spectroscopic data (and assignments) obtained from sesquiterpene 7 and 1D NMR data for 10-bromo-7,8-expoxychamigr-1-en-3-ol (8) [26]
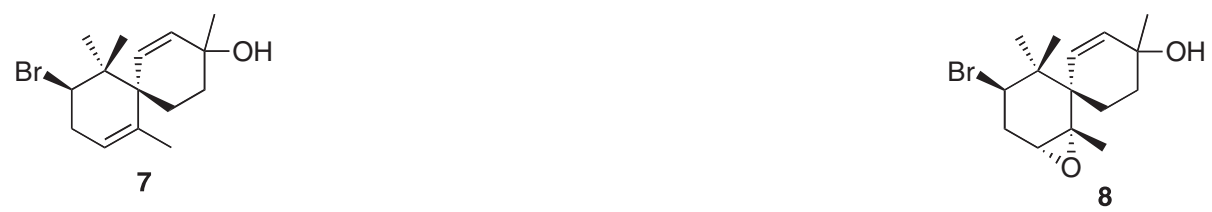

\begin{tabular}{|c|c|c|c|c|c|c|}
\hline Position & $\delta_{C}{ }^{a}$ type $^{b}$ & $\delta_{\mathrm{H}}(\mathrm{H}$, multi, $J \mathrm{~Hz})$ & ${ }^{1} \mathrm{H}-{ }^{1} \mathrm{H} \cos Y$ & HMBC & $\delta_{c}^{c}$ & $\delta_{\mathrm{H}}($ multi, $J \mathrm{~Hz})$ \\
\hline 1 & $136.4, \mathrm{CH}$ & $5.84(1 \mathrm{H}, \mathrm{d}, 10.4)$ & 2 & 6 & 136.1 & $5.84(\mathrm{dd}, 10.4,1.0)$ \\
\hline 2 & 131.1, CH & $5.53(1 \mathrm{H}, \mathrm{d}, 10.4)$ & 1 & $3,6,15$ & 131.3 & $5.73(\mathrm{dd}, 10.4,1.6)$ \\
\hline 3 & $67.5, q C$ & - & - & - & 66.8 & - \\
\hline 4 & $36.1, \mathrm{CH}_{2}$ & $1.80(1 \mathrm{H}, \mathrm{m}), 1.73(1 \mathrm{H}, \mathrm{m})$ & 5 & 3 & 35.0 & $1.79(m), 1.81(m)$ \\
\hline 5 & $28.2, \mathrm{CH}_{2}$ & $1.98(2 \mathrm{H}, \mathrm{m})$ & 4 & 3,6 & 23.1 & $1.69(\mathrm{ddd}, 13.2,11.2,4.7), 1.94(\mathrm{~d}, 13.2)$ \\
\hline 6 & 48.0, qC & - & - & - & 45.9 & - \\
\hline 7 & $139.0, q C$ & - & - & - & 60.5 & - \\
\hline 8 & $120.2, \mathrm{CH}$ & $5.22(1 \mathrm{H}, \mathrm{s})$ & 9,14 & - & 61.4 & $2.97(d, 3.0)$ \\
\hline 9 & $35.8, \mathrm{CH}_{2}$ & $2.78(1 \mathrm{H}, \mathrm{m}), 2.56(1 \mathrm{H}, \mathrm{m})$ & 8,10 & - & 35.1 & $2.40(\mathrm{ddd}, 15.4,11.4,3.0), 2.69(\mathrm{dd}, 15.4,5.8)$ \\
\hline 10 & 62.0, $\mathrm{CH}$ & $4.63(1 \mathrm{H}, \mathrm{dd}, 10.8,6.3)$ & $9 b$ & 12 & 58.4 & $4.28(\mathrm{dd}, 11.4,5.8)$ \\
\hline 11 & $41.5, q C$ & - & - & - & 40.0 & - \\
\hline 12 & $17.8, \mathrm{CH}_{3}$ & $1.01(3 \mathrm{H}, \mathrm{s})$ & 13 & 13 & 18.2 & $1.08(\mathrm{~s})$ \\
\hline 13 & $26.1, \mathrm{CH}_{3}$ & $1.10(3 \mathrm{H}, \mathrm{s})$ & 12 & $6,10,12$ & 25.8 & $0.98(s)$ \\
\hline 14 & $21.7, \mathrm{CH}_{3}$ & $1.55(3 \mathrm{H}, \mathrm{s})$ & 9 & & 26.0 & $1.17(\mathrm{~s})$ \\
\hline 15 & 28.6, $\mathrm{CH}_{3}$ & $1.29(3 \mathrm{H}, \mathrm{bs})$ & - & & 29.3 & $1.33(\mathrm{~s})$ \\
\hline
\end{tabular}

${ }^{\mathrm{a}}$ Data recorded in $\mathrm{CDCl}_{3}$ calibrated at $\delta \mathrm{H} 7.24$ ppm an for $\delta \mathrm{c} 77.0$ for residual solvent; ${ }^{\text {bin }}$ the case of a diasterotopic pair of hydrogens, 'a' denotes the downfield proton while ' $b$ ' denotes the up field proton; 'chemical shift for the carbons was inferred from HSQC and HMBC data. 
Table 2 Percentage growth inhibition by sesquiterpenes (1 to 7 )

\begin{tabular}{|c|c|c|c|c|c|c|}
\hline \multirow[b]{2}{*}{ Cell line } & \multicolumn{6}{|c|}{ Compound } \\
\hline & 1 & 2 & 3 & 4 & 5 & $6 / 7$ \\
\hline HT29 & $60 \pm 3$ & $12 \pm 2$ & $12 \pm 5$ & $>100$ & $<10$ & $10 \pm 5$ \\
\hline U8 $7^{\mathrm{b}}$ & $25 \pm 2$ & $13 \pm 6$ & $15 \pm 7$ & $52 \pm 2$ & $12 \pm 4$ & $15 \pm 6$ \\
\hline MCF-7' & $81 \pm 6$ & $<10$ & $<10$ & $>100$ & $<10$ & $<10$ \\
\hline $\mathrm{A} 2780^{\mathrm{d}}$ & $65 \pm 5$ & $<10$ & $<10$ & $99 \pm 1$ & $<10$ & $<10$ \\
\hline $\mathrm{H} 460^{\mathrm{e}}$ & $11 \pm 1$ & $<10$ & $<10$ & $71 \pm 1$ & $<10$ & $<10$ \\
\hline $\mathrm{A} 431^{\mathrm{f}}$ & $86 \pm 1$ & $<10$ & $<10$ & $>100$ & $<10$ & $<10$ \\
\hline Du1459 & $41 \pm 1$ & $23 \pm 6$ & $18 \pm 3$ & $92 \pm 2$ & $18 \pm 2$ & $17 \pm 3$ \\
\hline BE2-Ch & $>100$ & $<10$ & $<10$ & $>100$ & $<10$ & $<10$ \\
\hline SJ-G2 ${ }^{b}$ & $40 \pm 5$ & $<10$ & $10 \pm 3$ & $>100$ & $12 \pm 3$ & $14 \pm 3$ \\
\hline $\mathrm{MIA}^{\mathrm{i}}$ & $47 \pm 2$ & $12 \pm 4$ & $17 \pm 3$ & $92 \pm 2$ & $18 \pm 3$ & $19 \pm 2$ \\
\hline$S M A^{j}$ & $34 \pm 8$ & $<10$ & $<10$ & $95 \pm 1$ & $<10$ & $<10$ \\
\hline MCF10A & $10 \pm 6$ & $<10$ & $<10$ & $31 \pm 10$ & $<10$ & $<10$ \\
\hline
\end{tabular}

Isoaplysin (1), isolaurenisol (2), debromoisolaurinterol (3), debromoaplysinol (4), laur-11-en-10-ol (5), and a 1:1 mixture of the 3a-hydroxydebromoaplysin (6) and 10-bromo-1,7-dien-3-ol (7) against a panel of cancer and non-cancer derived cell lines at a single dose $(25 \mu \mathrm{M})$. Values are measured relative to an untreated control. ${ }^{a}$ Colon; ${ }^{b}$ glioblastoma; ${ }^{\text {b }}$ breast; ${ }^{\text {d }}$ ovarian; ${ }^{\mathrm{e}}$ lung; ${ }^{\mathrm{f}}$ skin; ${ }^{\mathrm{g}}$ prostate; ${ }^{h}$ neuroblastoma; ipancreas; ${ }^{j}$ glioblastoma (murine); ${ }^{k}$ breast (normal).

excellent levels of activity (for a potential lead compound) against the HT29 $(9.1 \mu \mathrm{M})$, A431 $(9.6 \mu \mathrm{M})$, and Du145 $(6.8 \mu \mathrm{M})$ cell lines [31]. Isoaplysin (1) and debromoaplysinol (4) differ only in the presence of the C3a-Br (1) and a $\mathrm{C} 3 \mathrm{a}-\mathrm{OH}$ (4) moiety, and 4 displays enhanced specific and broad spectrum cytotoxicity relative to 1 , suggesting that

Table 3 Growth inhibition $\left(\mathrm{Gl}_{50} \mu \mathrm{M}\right)$ of isoaplysin (1), isolaurenisol (2), and debromoaplysinol (4) against a panel of cancer and non-cancer derived cell lines

\begin{tabular}{|c|c|c|c|}
\hline \multirow[b]{2}{*}{ Cell line } & \multicolumn{3}{|c|}{ Compound } \\
\hline & 1 & 2 & 4 \\
\hline HT29a & $15 \pm 1.2$ & $>50$ & $9.1 \pm 1.1$ \\
\hline U87 & $40 \pm 0.6$ & $>50$ & $26 \pm 1.7$ \\
\hline$M C F-7^{C}$ & $20 \pm 1.3$ & $>50$ & $14 \pm 1.7$ \\
\hline$A 2780^{d}$ & $17 \pm 0.6$ & $>50$ & $10 \pm 1.7$ \\
\hline $\mathrm{H} 460^{\mathrm{e}}$ & $34 \pm 1.2$ & $>50$ & $18 \pm 0.3$ \\
\hline$A 431^{f}$ & $17 \pm 0.6$ & $>50$ & $9.6 \pm 0.9$ \\
\hline Du145 & $12 \pm 0.3$ & $>50$ & $6.8 \pm 0.3$ \\
\hline$B E 2-C^{h}$ & $27 \pm 2.3$ & $>50$ & $13 \pm 0.9$ \\
\hline SJ-G2 $2^{b}$ & $29 \pm 0.7$ & $>50$ & $15 \pm 0.7$ \\
\hline$M I A^{i}$ & $23 \pm 1.5$ & $>50$ & $16 \pm 0.7$ \\
\hline$S M A^{j}$ & $24 \pm 3.8$ & $>50$ & $14 \pm 1.2$ \\
\hline MCF10A ${ }^{k}$ & $46 \pm 3.2$ & $>50$ & $28 \pm 1.0$ \\
\hline
\end{tabular}

$\mathrm{Gl}_{50}$ is the concentration of drug that reduces cell growth by $50 \%$. ${ }^{\mathrm{a}} \mathrm{Colon}$; ${ }^{b}$ glioblastoma; ${ }^{\text {Cbreast; }}{ }^{\mathrm{d}}$ ovarian; ${ }^{\mathrm{e}}$ lung; ${ }^{\mathrm{f}}$ skin; ${ }^{\mathrm{g}}$ prostate; ${ }^{\mathrm{h}}$ neuroblastoma; ipancreas; ${ }^{\mathrm{j}}$ glioblastoma (murine); ${ }^{\mathrm{k}}$ breast (normal). the $-\mathrm{OH}$ moiety enhances the cytotoxicity of this class of compounds.

Sun et al. isolated and screened the related sesquiterpenes: aplysin-9-ene, epiaplysinol, debromoepiaplysinol, aplysinol, and aplysin isolated from Laurencia tristicha in a MTT assay against lung adenocarcinoma (A549), stomach cancer (BGC-823), hepatoma (Bel 7402), colon cancer (HCT-8), and HeLa cell lines [19]. Interestingly, only debromoepiaplysinol (epi-4, this work) displayed cytotoxicity with a $\mathrm{GI}_{50}=15.5 \mu \mathrm{M}$ against HeLa cells, where as herein, debromoaplysinol (4) displays activity across our panel of 11 cancer cell lines with strong activity in the HT29 $(9.1 \mu \mathrm{M}), \mathrm{A} 431(9.6 \mu \mathrm{M})$, and Du145 $(6.8 \mu \mathrm{M})$ cells [19]. These findings serve to emphasize the subtle nature of drug-ligand interactions and the role of stereochemistry in eliciting biological activity, c.f. 1,4 , and 6 .

\section{Conclusions}

Herein, we have identified sesquiterpenes $\mathbf{1}$ to $\mathbf{6}$ for the first time in L. pacifica and isolated a new sesquiterpene and 10-bromo-1,7-dien-3-ol (7). Screening of these analogues against 11 cancer cell lines revealed modest to good levels of cytotoxicity for $\mathbf{1}$ and $\mathbf{4}$, with up to fourfold selectivity towards cancer-derived cell populations compared with normal cells. Given the low molecular weights and high $\mathrm{Fsp} p^{3}$ content, the structure activity data elucidated in this small subset of analogues, we believe that $\mathbf{1}$ and $\mathbf{4}$ represent excellent leads for the development of selective and potent anticancer agents [31].

\section{Experimental}

General experimental Solvents. Solvents used for TLC, speedy column, and centrifugal chromatography were of bulk quality and were distilled from glass prior to use. In the case of HPLC, all of the solvents were HPLC grade and were filtered and degassed prior to their use. The solvent referred as LP (light petroleum), is a mixture of different alkanes with a boiling point $60^{\circ} \mathrm{C}$ to $80^{\circ} \mathrm{C}$.

Collection of the Mexican algae L. pacifica algae were collected on the coast of the Baja California Peninsula, Mexico. The algae was cleaned of epiphytes, rinsed with fresh water, and dried in the sun at the collection site. The specimens were stored at $-20^{\circ} \mathrm{C}$. A voucher specimen of $L$. pacifica was preserved on location in $5 \%$ formaldehyde and deposited in a private collection at the Algal Laboratory in the Interdisciplinary Center of Marine Sciences (CICIMAR), La Paz, B.C.S., Mexico, for taxonomical identification and future reference. Subsequently, in the laboratory, $10 \mathrm{~g}$ of dry algae was roughly torn or cut to small pieces and then ground with a mortar and pestle. The powdered algae was then submerged in $250 \mathrm{~mL}$ of ethanol. The mixture was left for $48 \mathrm{~h}$ at $25^{\circ} \mathrm{C}$ to $35^{\circ} \mathrm{C}$. 
Afterwards, the mixture was filtered and the residual algal tissue was extracted again under the same conditions. Both filtered extracts were combined and concentrated to dryness under reduced pressure at $40^{\circ} \mathrm{C}$ to obtain $c a$ $30 \mathrm{mg}$ of extract. These extracts were used for biological screening.

Extracts of L. pacifica and its fractionation Crude extract of $L$. pacifica $2 \mathrm{~kg}$ of algae was reduced to small pieces of $c a$ as before, and then submerged in $1 \mathrm{~L}$ of ethanol. The resulting mixture was left for $48 \mathrm{~h}$ at $25^{\circ} \mathrm{C}$ to $35^{\circ} \mathrm{C}$. Afterwards, the mixture was filtered and the residual algal tissue was extracted again under the same conditions. Both filtered extracts were combined and concentrated to dryness under reduced pressure at $40^{\circ} \mathrm{C}$ to obtain $2.2 \mathrm{~g}$ of extract. Fractionation of the crude extract was commenced with a speedy column resulting in 18 fractions [32]. All fractions were tested in the colorimetric assay; active fractions were then fractionated in normal phase HPLC until isolation of a pure compound.

NMR Proton and ${ }^{13} \mathrm{C}$ NMR spectra were recorded on a Bruker Ascend 400 or Bruker Ascend 600 (Madison, WI, USA). All NMR spectra were recorded as $\mathrm{CDCl}_{3}$ solutions; the solvent signal was used as internal standard for chemical shifts $\left({ }^{13} \mathrm{C} \delta 77.0 \mathrm{ppm}\right.$, and ${ }^{1} \mathrm{H} \delta$ $7.24 \mathrm{ppm}$ for the residual $\mathrm{CHCl}_{3}$ proton). All spectra, including HSQC, HMBC, distortionless enhancement by polarization transfer (DEPT135), distortionless enhancement by polarization transfer with retention of quaternaries (DEPTQ135), and (homonuclear) COSY-utilized standard Bruker pulse programs.

Cell culture and stock solutions Stock solutions were prepared as follows and stored at $-20^{\circ} \mathrm{C}$ : drugs were stored as $20 \mathrm{mM}$ solutions in DMSO. All cell lines were cultured at $37^{\circ} \mathrm{C}$, under $5 \% \mathrm{CO}_{2}$ in air. All cancer-derived cells lines were maintained in Dulbecco's modified Eagle's medium (Trace Biosciences, Sydney, Australia) supplemented with $10 \%$ fetal bovine serum, $10 \mathrm{mM}$ sodium bicarbonate, penicillin $(100 \mathrm{IU} / \mathrm{mL})$, streptomycin $(100 \mu \mathrm{g} /$ $\mathrm{mL})$, and glutamine $(4 \mathrm{mM})$. The non-cancer-derived breast cell line MCF10A was maintained in Dulbecco's modified Eagle's medium and Ham's F12 medium (1:1, Trace Biosciences, Sydney, Australia) supplemented with $5 \%$ heat inactivated horse serum, HEPES (20 mM), penicillin $(100 \mathrm{IU} / \mathrm{ml})$, streptomycin $(100 \mu \mathrm{g} / \mathrm{mL})$, glutamine (2 mM), epidermal growth factor $(20 \mathrm{ng} / \mathrm{ml})$, hydrocortisone $(500 \mathrm{mg} / \mathrm{ml})$, cholera toxin $(100 \mathrm{ng} / \mathrm{ml})$, and insulin $(10 \mu \mathrm{g} / \mathrm{mL})$.

In vitro growth inhibition assay Cells in logarithmic growth were transferred to 96-well plates. Cytotoxicity was determined by plating cells in duplicate in $100 \mathrm{~mL}$ medium at a density of 2,500 to 4,000 cells/well. On day 0 , (24 h after plating) when the cells were in logarithmic growth, $100 \mu \mathrm{L}$ medium with or without the test agent was added to each well. After $72 \mathrm{~h}$, drug exposure growth inhibitory effects were evaluated using the MTT (3-[4,5dimethyltiazol-2-yl]-2,5-diphenyl-tetrazolium bromide) assay and absorbance read at $540 \mathrm{~nm}$. Percentage growth inhibition was determined at a fixed drug concentration of $25 \mu \mathrm{M}$. A value of $100 \%$ is indicative of total cell growth inhibition. Those analogues showing appreciable percentage growth inhibition underwent further dose response analysis allowing for the calculation of a $\mathrm{GI}_{50}$ value. This value is the drug concentration at which cell growth is $50 \%$ inhibited based on the difference between the optical density values on day 0 and those at the end of drug exposure [20].

Isoaplysin: (3S,3aS,8bS)-3a-(Bromomethyl)-3,6,8b-trimethyl2,3,3a,8b-tetrahydro-1H-benzo[b]cyclopenta[d]furan (1)

Isolated as a white powder: $1.5 \mathrm{mg} ;[\alpha]_{\mathrm{D}}^{20}=-5.3^{\circ}(c$ 0.001, $\left.\mathrm{CH}_{3} \mathrm{OH}\right)$; IRv $v_{\max } 2,927(\mathrm{C}-\mathrm{H}), 2,858,1,620(\mathrm{C}=\mathrm{C})$, 1,593 $(\mathrm{C}=\mathrm{C}), 1,499,1,453(\mathrm{C}=\mathrm{C}), 1,423,1,376(\mathrm{C}-\mathrm{H})$, 1,268 (C-O), 1,135, $946 \mathrm{~cm}^{-1} ;{ }^{1} \mathrm{H}$ NMR $(400 \mathrm{MHz}$, $\left.\mathrm{CDCl}_{3}\right) \delta 6.88(\mathrm{~d}, J=7.6 \mathrm{~Hz}, 1 \mathrm{H}, \mathrm{H}-5), 6.66(\mathrm{dd}, J=7.5$, $0.7 \mathrm{~Hz}, 1 \mathrm{H}, \mathrm{H}-4), 6.58(\mathrm{~s}, 1 \mathrm{H}, \mathrm{H}-2), 3.66,3.56$ (ABq, $\left.J_{\mathrm{AB}}=11.1 \mathrm{~Hz}, 2 \mathrm{H}, \mathrm{H}-12\right), 2.27$ (s, 3H, H-15), 2.21 to $2.12(\mathrm{~m}, 1 \mathrm{H}, \mathrm{H}-10), 1.90$ to $1.83(\mathrm{~m}, 1 \mathrm{H}, \mathrm{H}-8 \mathrm{a}), 1.70$ to 1.60 (m, 2H, H-8b, H-9a), 1.50 (s, 3H, H-14), 1.20 to 1.13 (m, 1H, H-9b), 1.10 (d, J=6.7 Hz, 3H, H-13). ${ }^{13} \mathrm{C}$ NMR $\left(101 \mathrm{MHz}, \mathrm{CDCl}_{3}\right) \delta 158.8$ (qC, C-1), 138.3 (qC, C-3), 133.0 (qC, C-6), 122.2 (CH, C-5), $121.4(\mathrm{CH}, \mathrm{C}-4), 109.3$ $(\mathrm{CH}, \mathrm{C}-2), 97.2(q \mathrm{C}, \mathrm{C}-11), 55.5(q \mathrm{C}, \mathrm{C}-7), 43.7(\mathrm{CH}$, $\mathrm{C}-10), 42.6\left(\mathrm{CH}_{2}, \mathrm{C}-8\right), 34.6\left(\mathrm{CH}_{2}, \mathrm{C}-12\right), 31.5\left(\mathrm{CH}_{2}, \mathrm{C}-9\right)$, $22.9\left(\mathrm{CH}_{3}, \mathrm{C}-14\right), 21.5\left(\mathrm{CH}_{3}, \mathrm{C}-15\right), 13.8\left(\mathrm{CH}_{3}, \mathrm{C}-13\right)$.

Isolaurenisol: 2-[3-(Bromomethylene)-1,2-dimethylcyclopentyl]-5-methylphenol (2)

Isolated as a white solid: $2.5 \mathrm{mg} ;[\alpha]_{\mathrm{D}}^{20}=-7.2^{\circ}(c$ 0.0025, $\left.\mathrm{CH}_{3} \mathrm{OH}\right) ; \mathrm{IR} v_{\max } 3,513(\mathrm{O}-\mathrm{H}), 2,959(\mathrm{C}-\mathrm{H}), 2,929,2,870$, 1,616 $(\mathrm{C}=\mathrm{C}), 1,576(\mathrm{C}=\mathrm{C}), 1,514,1,454,1,412,1,294$ (C-H), 1,254 (C-O), 1,186, 1,123, 809, 787, 653 (C-Br) $\mathrm{cm}^{-1} ;{ }^{1} \mathrm{H}$ NMR $\left(400 \mathrm{MHz}, \mathrm{CDCl}_{3}\right) \delta 7.15(\mathrm{~d}, J=7.9 \mathrm{~Hz}$, $1 \mathrm{H}, \mathrm{H}-5), 6.68$ (dd, $J=7.9,1.0 \mathrm{~Hz}, 1 \mathrm{H}, \mathrm{H}-4), 6.57$ (d, $J=1.1 \mathrm{~Hz}, 1 \mathrm{H}, \mathrm{H}-2), 5.99$ (d, $J=2.0 \mathrm{~Hz}, 1 \mathrm{H}, \mathrm{H}-13), 5.06$ (s, $1 \mathrm{H}, \mathrm{OH}), 3.05$ to 2.95 (m, $1 \mathrm{H}, \mathrm{H}-11), 2.56(\mathrm{dt}, J=12.9$, $7.2 \mathrm{~Hz}, 1 \mathrm{H}, \mathrm{H}-8 \mathrm{a}), 2.25$ (s, 3H, H-15), 2.07 to 1.96 (m, $1 \mathrm{H}$, H-9a), 1.64 to 1.57 (m, 1H, H-8b), 1.45 (s, 3H, H-14), 1.42 to 1.36 (m, 1H, H-9b), 1.22 (d, J=7.2 Hz, 3H, H-12). ${ }^{13} \mathrm{C}$ NMR (101 MHz, $\left.\mathrm{CDCl}_{3}\right) \delta 160.2(q \mathrm{C}, \mathrm{C}-10), 153.3(q \mathrm{C}$, C-1), 138.0 ( $q \mathrm{C}, \mathrm{C}-3), 128.7$ ( $q \mathrm{C}, \mathrm{C}-6), 128.1(\mathrm{CH}, \mathrm{C}-5)$, 121.3 (CH, C-4), 118.2 (CH, C-2), 101.3 (CH, C-13), 52.0 (qC, C-7), $39.2(\mathrm{CH}, \mathrm{C}-11), 39.2\left(\mathrm{CH}_{2}, \mathrm{C}-8\right), 31.0\left(\mathrm{CH}_{2}, \mathrm{C}-\right.$ 9), $26.8\left(\mathrm{CH}_{3}, \mathrm{H}-14\right), 20.7\left(\mathrm{CH}_{3}, \mathrm{C}-15\right), 19.1\left(\mathrm{CH}_{3}, \mathrm{C}-12\right)$.

Debromoisolaurinterol: [(1R,3S)-1,3-dimethyl-2-methylenecyclopentyl]-5-methyl-2-phenol (3) 
Isolated as a colorless oil: ca $1 \mathrm{mg}$; IRv $v_{\max } 3,458(\mathrm{O}-\mathrm{H})$, 3,055 (C-H), 2,984 (C-H), 1,641 ( $=\mathrm{C}), 1,581(\mathrm{C}=\mathrm{C})$, $1,113(\mathrm{C}-\mathrm{H}) \mathrm{cm}^{-1} ;{ }^{1} \mathrm{H}$ NMR $\left(400 \mathrm{MHz}, \mathrm{CDCl}_{3}\right) \delta 7.21(\mathrm{~d}$, $J=8.0 \mathrm{~Hz}, 1 \mathrm{H}, \mathrm{H}-5), 6.71(\mathrm{dd}, J=8.0,1.1 \mathrm{~Hz}, 1 \mathrm{H}, \mathrm{H}-4)$, $6.65(\mathrm{~d}, J=1.4 \mathrm{~Hz}, 1 \mathrm{H}, \mathrm{H}-2), 5.54(\mathrm{~s}, 1 \mathrm{H}, \mathrm{OH}), 5.08(\mathrm{~d}$, $J=2.1 \mathrm{~Hz}, 1 \mathrm{H}, \mathrm{H}-12 \mathrm{a}), 4.93(\mathrm{~d}, J=2.4 \mathrm{~Hz}, 1 \mathrm{H}, \mathrm{H}-12 \mathrm{~b})$, 2.88 to 2.78 (m, $1 \mathrm{H}, \mathrm{H}-10$ ), 2.26 (s, 3H, H-15), 2.25 to 2.18 (m, 1H, H-8a), 2.07 to 1.98 (m, 1H, H-9a), 1.60 to 1.55 (m, 1H, H-8b, obscured), 1.46 (s, 3H, H-14), 1.41 to 1.36 (m, 1H, H-9b), 1.19 (d, J=7.0 Hz, 3H, H-13).

Debromoaplysinol: 3a-methanol, 1,2,3,8b-Tetrahydro3,6,8b-trimethylcyclopenta-3H-[b]benzofuran (4)

Isolated as a colorless oil: $c a 1 \mathrm{mg} ;[\alpha]_{\mathrm{D}}^{20}=0^{\circ}(c$ 0.001, $\left.\mathrm{CH}_{3} \mathrm{OH}\right) ; \mathrm{IR} v_{\max } 3,425(\mathrm{O}-\mathrm{H}), 2,940,2,871,1,588(\mathrm{C}=\mathrm{C})$, 1,499, 1,044 (C-O), $860 \mathrm{~cm}^{-1}$; ${ }^{1} \mathrm{H}$ NMR (400 MHz, CDCl 3 ) $\delta 6.90(\mathrm{~d}, J=7.6 \mathrm{~Hz}, 1 \mathrm{H}, \mathrm{H}-5), 6.66(\mathrm{dd}, J=7.5,0.7 \mathrm{~Hz}$, $1 \mathrm{H}, \mathrm{H}-4), 6.57$ (s, $1 \mathrm{H}, \mathrm{H}-2), 3.84\left(\mathrm{dABq}, J=12.4_{(\mathrm{AB})}\right.$, $4.3 \mathrm{~Hz}, 1 \mathrm{H}, \mathrm{H}-12 \mathrm{a}), 3.71\left(\mathrm{dABq}, J=12.4{ }_{(\mathrm{AB})}, 8.6 \mathrm{~Hz}, 1 \mathrm{H}\right.$, $\mathrm{H}-12 \mathrm{~b}$ ), 2.28 (s, 3H, H-15), 1.88 to 1.78 (m, 2H, H-10, H-8a), 1.72 (dd, $J=8.6,4.3 \mathrm{~Hz}, 1 \mathrm{H}, \mathrm{OH}), 1.66$ to 1.60 (m, 2H, H-8b, H-9a), 1.46 (s, 3H, H-14), 1.16 to 1.11 (m, 1H, H-9b), 1.08 (d, J=6.8 Hz, 3H, H-13). ${ }^{13} \mathrm{C}$ NMR $\left(101 \mathrm{MHz}, \mathrm{CDCl}_{3}\right) \delta 159.1$ (qC, C-1), 138.3 (qC, C-3), 133.3 (qC, C-6), 122.2 (CH, C-5), 121.2 (CH, C-4), 109.0 $(\mathrm{CH}, \mathrm{C}-2), 99.6(q \mathrm{C}, \mathrm{C}-11), 63.9\left(\mathrm{CH}_{2}, \mathrm{C}-12\right), 54.2(q \mathrm{C}$, C-7), 42.3 (CH, C-10), $42.3\left(\mathrm{CH}_{2}, \mathrm{C}-8\right), 31.5\left(\mathrm{CH}_{2}, \mathrm{C}-9\right)$, $22.9\left(\mathrm{CH}_{3}, \mathrm{C}-14\right), 21.2\left(\mathrm{CH}_{3}, \mathrm{C}-51\right), 13.7\left(\mathrm{CH}_{3}, \mathrm{C}-13\right)$.

Laur-11-en-10-ol. 3-(4'-Methylphenyl)-1,3, dimethyl-2methylidenecyclopentanol (5)

Isolated as a colorless oil: ca $1 \mathrm{mg} ;{ }^{1} \mathrm{H}$ NMR $(600 \mathrm{MHz}$, $\left.\mathrm{CDCl}_{3}\right) \delta 7.21(\mathrm{~d}, J=7.9 \mathrm{~Hz}, 2 \mathrm{H}, \mathrm{H}-1, \mathrm{H}-5), 7.07$ (d, $J=8.1 \mathrm{~Hz}, 2 \mathrm{H}, \mathrm{H}-2, \mathrm{H}-4), 5.44$ (s, 1H, H-12a), 4.99 (s, 1H, H-12b), 3.47 (d, J=5.9 Hz, 1H, OH), 2.29 (s, 3H, H-15), 2.08 to 2.04 (m, $1 \mathrm{H}, \mathrm{H}-8 \mathrm{a}), 1.98$ to 1.92 (m, $1 \mathrm{H}, \mathrm{H}-8 \mathrm{~b})$, 1.82 to 1.77 (m, $1 \mathrm{H}, \mathrm{H}-9 \mathrm{a}), 1.67$ to $1.62(\mathrm{~m}, 1 \mathrm{H}, \mathrm{H}-9 \mathrm{~b}$, obscured), 1.48 (s, 3H, H-14), 1.36 (s, 3H, H-13). ${ }^{13} \mathrm{C}$ NMR (151 MHz, $\left.\mathrm{CDCl}_{3}\right) \delta 166.4(q \mathrm{C}, \mathrm{C}-11), 145.4(q \mathrm{C}$, C-6), 135.3 (qC, C-3), $129.0(2 \times \mathrm{CH}, \mathrm{C}-2, \mathrm{C}-4), 126.3$ (2 $\times \mathrm{CH}, \mathrm{C}-1, \mathrm{C}-5), 108.6\left(\mathrm{CH}_{2}, \mathrm{C}-12\right), 79.3(q \mathrm{C}, \mathrm{C}-10)$, 50.3 (qC, C-7), $39.5\left(\mathrm{CH}_{2}, \mathrm{C}-8\right), 39.2\left(\mathrm{CH}_{2}, \mathrm{C}-9\right), 30.8$ $\left(\mathrm{CH}_{3}, \mathrm{C}-14\right)$, 28.4 $\left(\mathrm{CH}_{3}, \mathrm{C}-13\right), 21.2\left(\mathrm{CH}_{3}, \mathrm{C}-15\right)$.

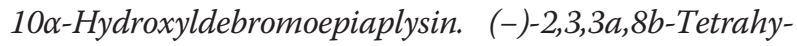
dro-3-hydroxy-3,3a,6,8b-tetramethyl-1H-benzocyclopentafuran (6)

Isolated as a colorless oil: ca $1 \mathrm{mg} ;{ }^{1} \mathrm{H}$ NMR $(600 \mathrm{MHz}$, $\left.\mathrm{CDCl}_{3}\right) \delta 6.92(\mathrm{~d}, J=7.6 \mathrm{~Hz}, 1 \mathrm{H}, \mathrm{H}-5), 6.66(\mathrm{~d}, J=7.4 \mathrm{~Hz}$, $1 \mathrm{H}, \mathrm{H}-4), 6.49$ (s, 1H, H-2), 5.35 (bs, 1H, OH), 2.26 (s, 3H, $\mathrm{H}-15$ ), 2.01 to 1.96 (m, $1 \mathrm{H}, \mathrm{H}-8 \mathrm{a}$, obscured), 1.76 to 1.71 (m, $1 \mathrm{H}, \mathrm{H}-8 \mathrm{~b}$, obscured), 1.61 to 1.57 (m, 2H, H-9, obscured), 1.39 (s, 3H, H-13), 1.38 (s, 3H, H-14), 1.28 (s, 3H, $\mathrm{H}-12) .{ }^{13} \mathrm{C}$ NMR (151 MHz, $\left.\mathrm{CDCl}_{3}\right) \delta 158.0(q \mathrm{C}, \mathrm{C}-1)$, 138.1 (qC, C-3), 133.5 (qC, C-6), $122.5(\mathrm{CH}, \mathrm{C}-5), 121.0$ (CH, C-4), 109.6 (CH, C-2), 100.5 (qC, C-11), 82.9 (qC,
C-10), 53.6 (qC, C-7), $40.8\left(\mathrm{CH}_{2}, \mathrm{C}-8\right), 37.0\left(\mathrm{CH}_{2}, \mathrm{C}-9\right)$, $23.4\left(\mathrm{CH}_{3}, \mathrm{C}-14\right), 22.2\left(\mathrm{CH}_{3}, \mathrm{C}-13\right), 21.1\left(\mathrm{CH}_{3}, \mathrm{C}-15\right)$, $14.8\left(\mathrm{CH}_{3}, \mathrm{C}-12\right)$.

10-Bromo-3,7,11,11-tetramethylspiro[5.5] undeca-1,7-dien3-ol (7)

Isolated as a colorless oil: ca $0.1 \mathrm{mg} ;{ }^{1} \mathrm{H}$ NMR $(600 \mathrm{MHz}$, $\left.\mathrm{CDCl}_{3}\right) \delta 5.84(\mathrm{~d}, J=10.4 \mathrm{~Hz}, 1 \mathrm{H}, \mathrm{H}-4), 5.53(\mathrm{~d}, J=10.5 \mathrm{~Hz}$, $1 \mathrm{H}, \mathrm{H}-5), 5.22$ (s, $1 \mathrm{H}, \mathrm{H}-8), 4.63$ (dd, $J=10.8,6.3 \mathrm{~Hz}$, $1 \mathrm{H}, \mathrm{H}-10), 2.65$ to 2.59 (m, $1 \mathrm{H}, \mathrm{H}-9 \mathrm{a}), 2.57$ to 2.50 (m, $1 \mathrm{H}, \mathrm{H}-9 \mathrm{~b}), 2.02$ to 1.96 (m, $2 \mathrm{H}, \mathrm{H}-1), 1.82$ to 1.77 (m, $1 \mathrm{H}$, $\mathrm{H}-2 \mathrm{a}), 1.76$ to 1.71 ( $\mathrm{m}, 1 \mathrm{H}, \mathrm{H}-2 \mathrm{~b}$, obscured), 1.55 (s, 3H, $\mathrm{H}-14$, obscured), 1.29 (s, 3H, H-15), 1.10 (s, 3H, H-13), 1.01 (s, 3H, H-12). $\left.{ }^{13} \mathrm{C} \mathrm{NMR} \mathrm{(151} \mathrm{MHz,} \mathrm{CDCl}_{3}\right) \delta 139.0$ (qC, C-7), $136.4(\mathrm{CH}, \mathrm{C}-4), 131.1(\mathrm{CH}, \mathrm{C}-5), 120.7(\mathrm{CH}$, C-8), 67.5 (qC, C-3), 61.3 (CH, C-10), 47.1 (qC, C-6), 41.5 $(q \mathrm{C}, \mathrm{C}-11), 36.1\left(\mathrm{CH}_{2}, \mathrm{C}-2\right), 35.8\left(\mathrm{CH}_{2}, \mathrm{C}-9\right), 28.6\left(\mathrm{CH}_{3}\right.$, C-15), $28.2\left(\mathrm{CH}_{2}, \mathrm{C}-1\right), 26.1\left(\mathrm{CH}_{3}, \mathrm{C}-13\right), 21.7\left(\mathrm{CH}_{3}\right.$, $\mathrm{C}-14), 17.8\left(\mathrm{CH}_{3}, \mathrm{C}-12\right)$.

\section{Additional file}

Additional file 1: Structural characterization.

\section{Competing interests}

The authors declare that they have no competing interests.

\section{Acknowledgements}

DZAP gratefully acknowledges scholarship support from the Mexican government (Nacional Councli of Science and Technology (Consejo Nacional de Ciencia y Technologia, CONCYT)) and the University of Newcastle.

\section{Author details}

${ }^{1}$ Chemistry, School of Environmental and Life Science, The University of Newcastle, University Drive, Callaghan, NSW 2308, Australia. ${ }^{2}$ Development Technology Department, Interdisciplinary Centre of Marine Sciences, National Technological Institute, La Paz, Mexico. ${ }^{3}$ Department of Medical Oncology, Calvary Mater Newcastle Hospital, Waratah, NSW 2298, Australia.

Received: 3 June 2014 Accepted: 17 August 2014 Published online: 20 September 2014

\section{References}

1. López-Vallejo F, Giulianotti MA, Houghten RA, Medina-Franco JL (2012) Expanding the medicinally relevant chemical space with compound libraries. Drug Dis Today 17:718-726

2. Newman DJ, Cragg GM (2012) Natural products as sources of new drugs over the 30 years from 1981 to 2010. J Nat Prod 75:311-335

3. Harvey AL (2008) Natural products in drug discovery. Drug Dis Today 13:894-901

4. Lipinski CA, Lombardo F, Dominy BW, Feeney PJ (2001) Experimental and computational approaches to estimate solubility and permeability in drug discovery and development settings. Adv Drug Deliv Rev 46:3-26

5. Koehn FE, Carter GT (2005) The evolving role of natural products in drug discovery. Nat Rev Drug Dis 4:206-220

6. Newman DJ (2008) Natural products as leads to potential drugs: an old process or the new hope for drug discovery? J Med Chem 51:2589-2599

7. Holland IP, McCluskey A, Sakoff JA, Chau N, Robinson PJ, Motti CA, Wright AD, Van Altena IA (2009) New cytotoxic steroids from an Australian sponge Psammoclema sp. J Nat Prod 72:102-106

8. Wright AD, McCluskey A, Robertson MJ, MacGregor K, Gordon CP, Guenther J (2011) Anti-malarial, anti-algal, anti-tubercular, anti-bacterial, anti-photosynthetic, and anti-fouling activity of diterpene and diterpene isonitriles from the tropical sponge Cymbastela hooperi. Org Biomol Chem 9:400-407 
9. Maschek J, Baker B (2008) The chemistry of algal secondary metabolism. In: Maschek J, Baker B (ed) Algal Chemical Ecology. Springer, Germany, pp 1-20. Chapter 1

10. Eickson KL (1983) Constituents of Laurencia. In: Scheuer PJ (ed) Marine Natural Products: Chemical and Biological Perspectives, vol 5. Academic, USA, pp 131-257. Chapter 4

11. Ji N-Y, Xiao-Ming Li X-M, Lia K, Bin-Gui Wang B-G (2009) Halogenated sesquiterpenes from the marine red alga Laurencia saitoi (Rhodomelaceae). Helvet Chim Acta 92:1873-1897

12. Hay ME (2009) Marine chemical ecology: chemical signals and cues structure marine populations, communities, and ecosystems. Annu Rev Mar Sci 1:193-212

13. Shui-Chun M, Yue-Wei G (2010) Sesquiterpenes from Chinese red alga Laurencia okamurai. Chin J Nat Med 8:321-325

14. Crews P, Selover SJ (1986) Comparison the sesquiterpenes from the seaweed Laurencia pacifica and its epiphyte Erythrocystis saccata. Phytochemistry 25:1847-1852

15. Sims JJ, Fenical W, Wing RM, Radlick P (1973) Marine natural products. IV Prepacifenol, a halogenated epoxy sesquiterpene and precursor to pacifenol from the red alga, Laurencia filiformis. J Am Chem Soc 95:972-972

16. Sims JJ, Donnell MS, Leary JV, Lacy GH (1975) Antimicrobial agents from marine algae. Antimicrob Agents Chemother 7:320-321

17. Dembitsky VM, Gloriozova TA, Poroikov W (2007) Natural peroxy anticancer agents. Mini-Rev Med Chem 7:571-589

18. Sun J, Shi D, Ma M, Li S, Wang S, Han L, Yang Y, Fan X, Shi J, He L (2005) Sesquiterpenes from the red alga Laurencia tristicha. J Nat Prod 68:915-919

19. Sun J, Shi D, Li S, Wang S, Han L, Fan X, Yang Y, Shi J (2007) Chemical constituents of the red alga Laurencia triticha. J Asian Nat Prod Res 9:725-734

20. Thaqi A, Scott JL, Gilbert J, Sakoff JA, McCluskey A (2010) Synthesis and biological activity of $\Delta-5,6$-norcantharimides: importance of the 5,6-bridge. Eur J Med Chem 45:1717-1723

21. Suzuki M, Kurosawa E (1978) New aromatic sesquiterpenoids from the red alga Laurencia Okamurai yamada. Tetrahedron Lett 28:2503-2506

22. Suziki M, Kurata K, Kurosawa E (1986) The structure of isoaplysin, a brominated rearranged cuparane-type sesquiterpenoid from the red alga Laurencia okamurai Yamada. Bull Chem Soc Jpn 59:3981-3982

23. Harrowven DC, Lucas MC, Howes PD (2001) The synthesis of a natural product family: from debromoisoluaurinterol to the aplysins. Tetrahedron 57:791-804

24. Blunt JW, Lake RJ, Munro MHG (1984) Sesquiterpenes from the marine red alga Laurencia distichophylla. Phytochemistry 23:1951-1954

25. Yamada K, Yazawa H, Uemura D, Toda M, Hirata Y (1969) Total synthesis of $( \pm$ )aplysin and $( \pm)$ debromoaplysin. Tetrahedron 25:3509-3520

26. Li X-D, Miao F-P, Li K, Ji N-Y (2012) Sesquiterpenes and acetogenins from the marine red alga Laurencia okamurai. Fitoterapia 83:518-522

27. Davyt D, Fernandez R, Suescun L, Mombrú AW, Saldaña J, Domínguez L, Coll J, Fujii MT, Manta E (2001) New sesquiterpene derivatives from the red alga Laurencia scoparia: isolation, structure determination, and anthelmintic activity. J Nat Prod 64:1552-1555

28. König GM, Wright AD (1997) Laurencia rigida: chemical investigation of its antifouling dichloromethane extract. J Nat Prod 60:967-970

29. Suescun L, Mombrú AW, Mariezcurrena RA, Davyt D, Fernandez R, Manta E (2001) Two natural products from the alga Laurencia scoparia. Acta Cryst Section C C57:286-288

30. Kelman D, Wright AD (2012) The importance of ${ }^{1} \mathrm{H}$-nuclear magnetic resonance spectroscopy for reference standard validation in analytical sciences. PLoS One 7:e42061

31. Leeson PD, Springthorpe B (2007) The influence of drug-like concepts on decision-making in medicinal chemistry. Nat Rev Drug Dis 6:881-890

32. Harwood LM (1985) Dry-column flash chromatography. Aldrichimica Acta $18: 25-26$

doi:10.1186/s13588-014-0008-8

Cite this article as: Zaleta-Pinet et al:: Cytotoxic compounds from

Laurencia pacifica. Organic and Medicinal Chemistry Letters 2014 4:8.

\section{Submit your manuscript to a SpringerOpen ${ }^{\odot}$ journal and benefit from:}

- Convenient online submission

- Rigorous peer review

- Immediate publication on acceptance

- Open access: articles freely available online

- High visibility within the field

- Retaining the copyright to your article

Submit your next manuscript at $\gg$ springeropen.com 